Vol. 2 No. 3 (2019) pp. 97-103

Available online at http://journal.ummgl.ac.id/index.php/AutomotiveExperiences

p-ISSN: 2615-6202 e-ISSN: 2615-6636

Research Paper

\title{
Effect of Cassava Biogasoline on Fuel Consumption and CO Exhaust Emissions
}

\author{
Mujahid Wahyu' ${ }^{*}$, Hadi Rahmad1, Gabriel Jeremy Gotama ${ }^{2,3}$ \\ ${ }^{1}$ Department of Mechanical Engineering, PSDKU Polinema Kediri, Indonesia, 64121 \\ ${ }^{2}$ School of Mechanical and Aerospace Engineering, Nanyang Technological University, Singapore, 639798 \\ ${ }^{3}$ Department of Mechanical Engineering, Technical University of Munich, Garching, Germany, 85748
}

Email: mujahid.wahyu89@gmail.com

doi: https://doi.org/10.31603/ae.v2i3.2991

Check for updates

\begin{abstract}
Article Info Cassava biogasoline was tested on electronic fuel injection vehicles in urban traffic conditions Submitted: with varying engine load. Biogasoline tested includes B0, B10, B20, and B30. The engine speed

24/09/2019

Revised: was operated within 750 to $1800 \mathrm{rpm}$ (low-speed range) to simulate urban traffic condition. The engine load was varied through the operation of air conditioner (AC). Fuel consumption 23/10/2019 Accepted: $08 / 11 / 2019$ was measured in real terms $(\mathrm{ml} / \mathrm{s})$ and $\mathrm{CO}$ emissions were measured with the Hesbon HG 520 Engine Gas Analyzer (EGA) in the percentage of total exhaust gas. The results showed that $B 10$ has the lowest fuel consumption of $0.24 \mathrm{ml} / \mathrm{s}$ in conditions without $\mathrm{AC}$ and $0.41 \mathrm{ml} / \mathrm{s}$ with AC. Meanwhile, $\mathrm{CO}$ emissions tend to be constant with change in the proportion of cassava biogasoline and increased with additional AC load.
\end{abstract}

Key words: Biogasoline, Fuel consumption, $\mathrm{CO}$ emissions

\begin{abstract}
Abstrak
Biogasoline singkong diujikan pada kendaraan electronic fuel injection pada kondisi lalu lintas perkotaan dan variasi pembebanan mesin. Biogasoline yang diujikan meliputi B0, B10, B20, dan B30. Kondisi lalu lintas perkotaan menjadikan putaran mesin terkontrol pada kisaran putaran rendah, \pm 750 s.d $1800 \mathrm{rpm}$ dengan air conditioner (AC) sebagai variasi beban mesin. Konsumsi bahan bakar diukur secara riil $(\mathrm{ml} / \mathrm{s})$ dan emisi $\mathrm{CO}$ diukur dengan Engine Gas Analizer (EGA) Hesbon HG 520 secara persentase dari total emisi gas buang. Hasil penelitian menunjukkan B10 menghasilkan konsumsi bahan bakar terendah yaitu $0.24 \mathrm{ml} / \mathrm{s}$ pada kondisi tanpa AC dan $0.41 \mathrm{ml} / \mathrm{s}$ dengan AC. Sementara itu, Emisi CO cenderung konstan dengan perubahan proporsi biogasoline singkong dan meningkat dengan tambahan beban AC.
\end{abstract}

Kata Kunci: Biogasoline, Konsumsi bahan bakar, Emisi CO

\section{Introduction}

In 2017, Central Bureau of Statistics Republic of Indonesia (Badan Pusat Statistik, BPS) released data on the number of motorized vehicles in Indonesia reaching $138,556,669$ units [1]. The number increased by $9,275,590$ units compared to the previous year. The types of motorized vehicles include passenger cars, bus cars, freight cars and motorbikes.

The increasing number of motorized vehicles has caused serious problems in the field of energy and environment [2]. In the energy sector, there is an increase in fuel demand. According to BPH Migas, in 2018, it is estimated that fuel 
consumption has reached 75 million kilo liters and has increased by 1.44 million kilo liters compared to 2017. The increase in the number of motorized vehicles has an adverse effect on the environment (air quality index). Motorized vehicles become a source of carbon monoxide produced from incomplete combustion processes; which contribute to $75 \%$ of total carbon dioxide in rural area and 95\% in urban area [3].

The increase in motor vehicles has also caused traffic congestion in almost all major cities in Indonesia. For example, a study by Prasetyo et al. suggested that traffic jam at one traffic light point brings a loss of IDR 4,950,000 to IDR $9,940,000$ per day [4]. Moreover, a report from the University of Indonesia environmental expert, Dr. Firdaus Ali, stated that the loss due to traffic congestion in Indonesia reached IDR. 28.1 trillion per year [5].

Therefore, biofuels such as biogasoline, both as it is and as a mixture, are needed for a sustainable transportation system. Biogasoline itself is an alternative energy produced from plants such as corn, sugar cane, and cassava [6][9]. Biogasoline from biomass is able to produce lower exhaust emissions compared to gasoline [10]. In 2013, 85\% of biofuel supplies produced by the United States and Brazil came from corn and sugar cane [11]. The use of biogasoline in vehicles reduces carbon dioxide emissions by $48 \%$ compared to conventional gasoline [12]. The use of biogasoline may also increase the thermal efficiency [13].

The use of biogasoline as an alternative energy is expected to be implemented in various types of vehicle technology. Previous studies have confirmed that the use of biogasoline in the Toyota Corolla Twincam AE92 type carburetor can reduce $\mathrm{CO}$ emissions in idle rotation testing [14]. Currently, the fuel control system technology has switched to Electronic Fuel Injection (EFI) with its variations. EFI technology is designed to allow the acquisition of lambda $(\lambda)$ to approach ideal values under various engine conditions [15]. Lambda is the number used to represent the ideal air-fuel ratio (AFR), $\lambda=1$. Based on this background, this study specifically intends to address the effect of the use of cassava biogasoline on fuel consumption and exhaust emissions on EFI vehicles in conditions of urban traffic and varying engine load.

\section{Method}

\subsection{Engine preparation}

Cassava biogasoline has been applied to the 1300 CC EFI car equipped with an AC system. Cassava biogasoline has been made through the process of cassava glucose fermentation. The experiment was conducted by firstly modifying the fuel components through the addition of a special fuel tank, as shown in Figure 1. EFI engine scheme is presented in Figure 2 [16].

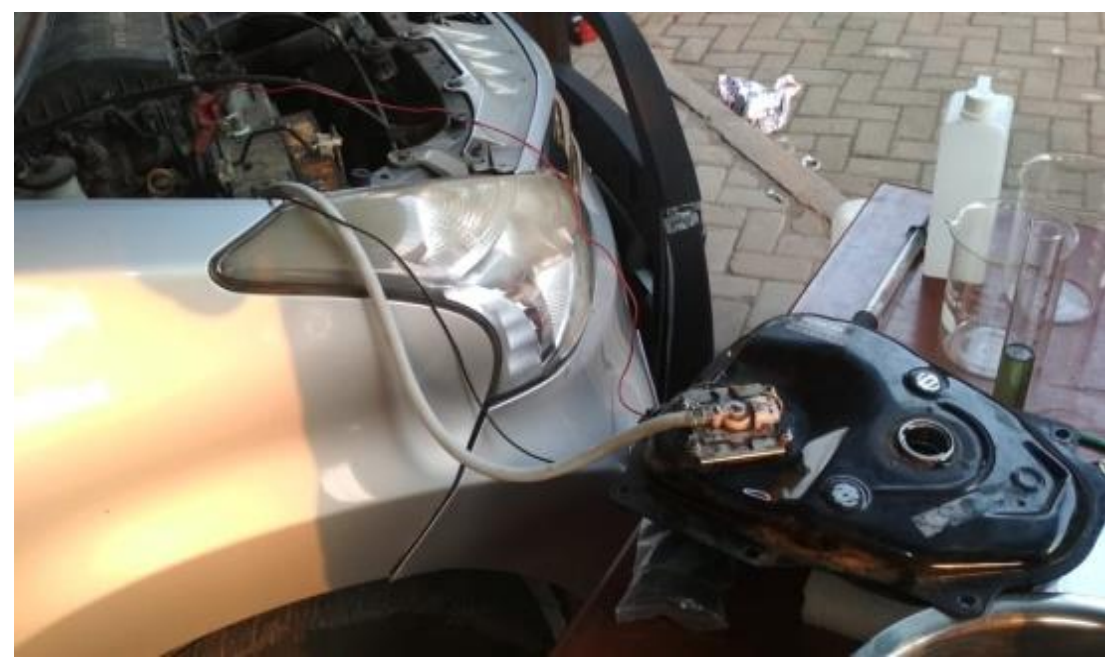

Figure 1. Special fuel tank for cassava biogasoline experimental test 


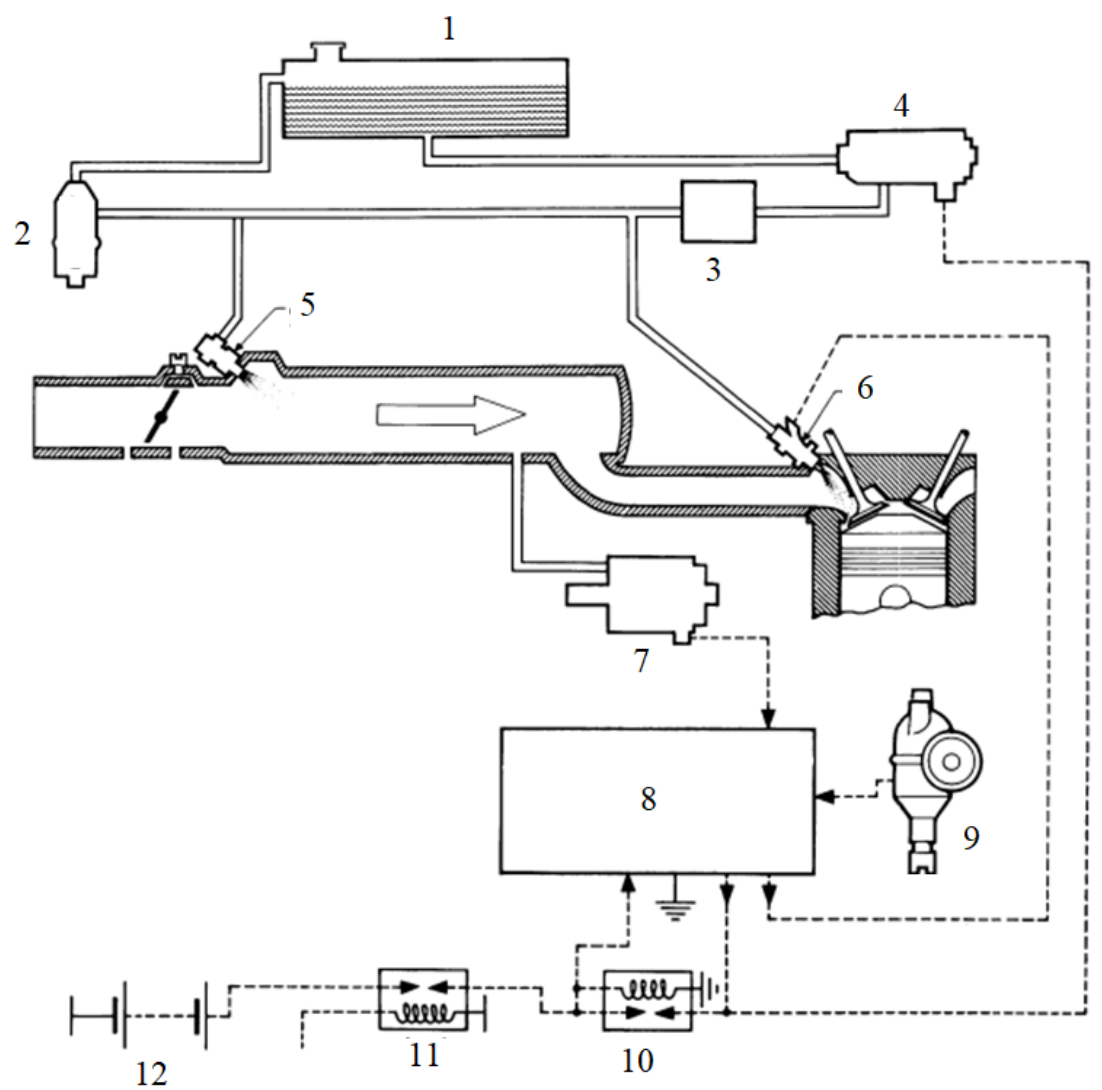

Figure 2. EFI fuel system: (1) fuel tank, (2) regulator, (3) filter, (4) fuel pump, (5) cold start injector, (6) injector, (7) pressure sensor, (8) ECU, (9) distributor, (10) fuel pump relay, (11) main relay, dan (12) battery.

\subsection{Fuel consumption measuring}

Biogasoline used in this study included B0 (100\% gasoline RON-92), B10 (10\% cassava bioethanol and 90\% gasoline RON-92), B20 (20\% cassava bioethanol and 80\% gasoline RON-92), and B30 (30\% bioethanol cassava and 70\% gasoline RON-92). All specified mixtures are tested like in urban cycle conditions; with and without AC system load.

Testing the fuel consumption involves measuring cups to measure the volume of fuel (ml) spent in each treatment (s). Fuel consumption is calculated from the start of the engine until the engine runs out of fuel supply. Therefore, manipulation of the fuel pump relay line is required.

Tests were carried out on vehicles running in static conditions. The engine is set to run for 10 minutes under urban traffic condition, with sequence of: 2 minutes stationary, 2 minutes low engine speed (1800 rpm), 2 minutes stationary, 2 minutes low engine speed (1800 rpm), and stationary for the last 2 minutes remaining. After 10 minutes (600 seconds), the fuel supply is cut out and the engine is left until it stops. The evolution of engine speed during the test is presented in Figure 3.

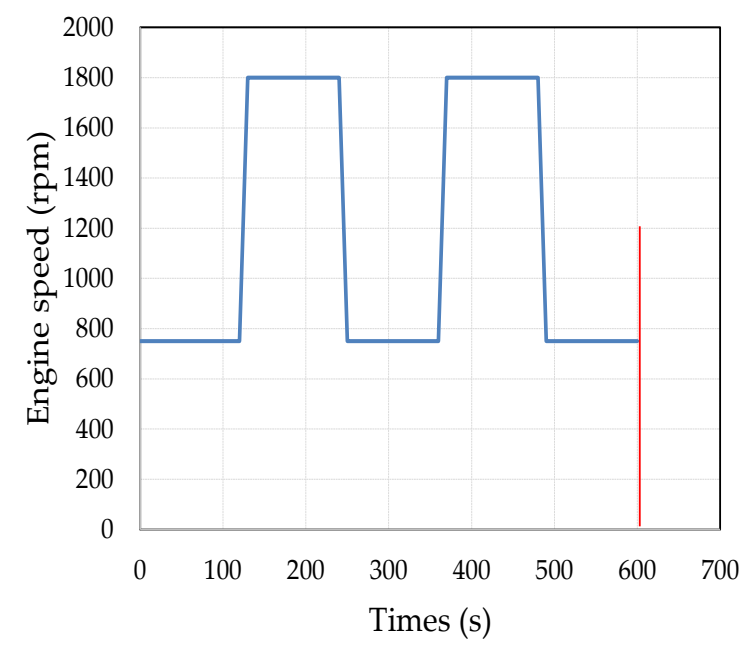

Figure 3. The evolution of engine speed during the test (The vertical red line in the 600th second indicates the cease of fuel pump operation) 


\subsection{Emission measuring}

Exhaust emission testing uses Hesbon HG 520 Engine Gas Analyzer (EGA) at idle rotation. The exhaust emission check was done by firstly conducting a visual inspection to ensure all tools and components are in normal condition, especially to avoid leakage in the vehicle exhaust pipe. After the visual inspection, the engine was turned on and left idle until it reaches steady engine condition. Next, the EGA probe was placed in the exhaust pipe and the engine was accelerated to $3000 \mathrm{rpm}$ for 30 seconds. Finally, the engine was left to idle for a few seconds to obtain the emissions data.

\section{Result and Discussion}

\subsection{Fuel consumption}

The results of the fuel consumption test and operational time are presented in Table 1. Each fuel was tested twice for condition with and without AC load. The comparison of the fuel consumption is presented in Figure 4. It is discovered that the use of biogasoline can reduce the fuel consumption. Highest reduction of fuel consumption is found with B10 fuel without AC load.

Table 1. Fuel consumption test results

\begin{tabular}{rcccc}
\hline \multirow{2}{*}{ Fuel } & AC & Time & \multicolumn{2}{c}{ Consumption } \\
\cline { 4 - 5 } & Load & $(\mathbf{s})$ & $(\mathbf{m l})$ & $(\mathbf{m l} / \mathbf{s})$ \\
\hline B0 & Off & 613.25 & 236 & 0.38 \\
B0 & On & 613.14 & 286 & 0.47 \\
B10 & Off & 614.01 & 148 & 0.24 \\
B10 & On & 613.23 & 250 & 0.41 \\
B20 & Off & 614.55 & 232 & 0.38 \\
B20 & On & 614.03 & 272 & 0.44 \\
B30 & Off & 614.45 & 228 & 0.37 \\
B30 & On & 614.20 & 269 & 0.44 \\
\hline
\end{tabular}

\subsection{Emission}

Emission test is performed at idle speed and engine operating temperature. In this study, CO and $\mathrm{O}_{2}$ are shown in percentage of total emission. $\mathrm{CO}$ is a harmful component in exhaust gas that originated from incomplete combustion process. Mixture is considered lean if value of $\lambda$ is larger than one $(\lambda>1)$ and rich if value of $\lambda$ is less than one $(\lambda<1)$. The $\mathrm{O}_{2}$ content in the exhaust gas is used to ensure the AFR $(\lambda)$ value can be used as a reference. $\mathrm{O}_{2}$ value above $3 \%$ is confirmed to have an exhaust leak and therefore the AFR $(\lambda)$ value cannot be used as reference. The results of the exhaust emission tests for all fuels tested are presented in Table 2.

Table 2. Exhaust emission test results with biogasoline

\begin{tabular}{ccccc}
\hline Fuel & AC Load & $\begin{array}{c}\text { CO } \\
(\mathbf{\%})\end{array}$ & $\begin{array}{c}\text { Lambda } \\
(\lambda)\end{array}$ & $\begin{array}{c}\mathbf{O}_{2} \\
\mathbf{( \% )}\end{array}$ \\
\hline B0 & Off & 0.01 & 1.003 & 0.13 \\
B0 & On & 0.01 & 1.002 & 0.09 \\
B10 & Off & 0.01 & 1.002 & 0.07 \\
B10 & On & 0.02 & 1.000 & 0.04 \\
B20 & Off & 0.03 & 0.999 & 0.10 \\
B20 & On & 0.04 & 0.998 & 0.06 \\
B30 & Off & 0.01 & 1.003 & 0.09 \\
B30 & On & 0.02 & 1.002 & 0.09 \\
\hline
\end{tabular}

Based on Table 2, it is found that the percentage $\mathrm{CO}$ emissions with various percentage of biogasoline variations tend to be the same. The largest difference is found in the percentage of $\mathrm{CO}$ value of B20; which is $0.04 \%$ and $0.03 \%$ with and without operating $\mathrm{AC}$, respectively. It is also discovered that additional load from operating $\mathrm{AC}$ tends to increase the $\mathrm{CO}$ emissions. Based on the Government Regulation No. 5/2006, the maximum $\mathrm{CO}$ gas emission limit is $1.5 \%$; Therefore, $\mathrm{CO}$ emissions on EFI engines with various biogasoline mixes are still within the regulation limit. Breakdowns of $\mathrm{CO}, \lambda$, and $\mathrm{O}_{2}$ comparisons are presented in Figure 5, Figure 6, and Figure 7, respectively. 


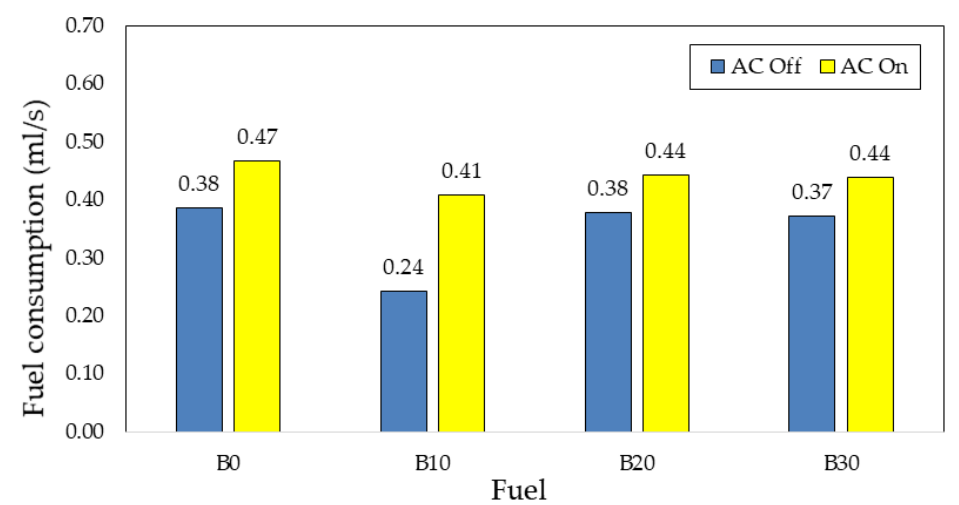

Figure 4. Comparison of fuel consumption with and without AC load.

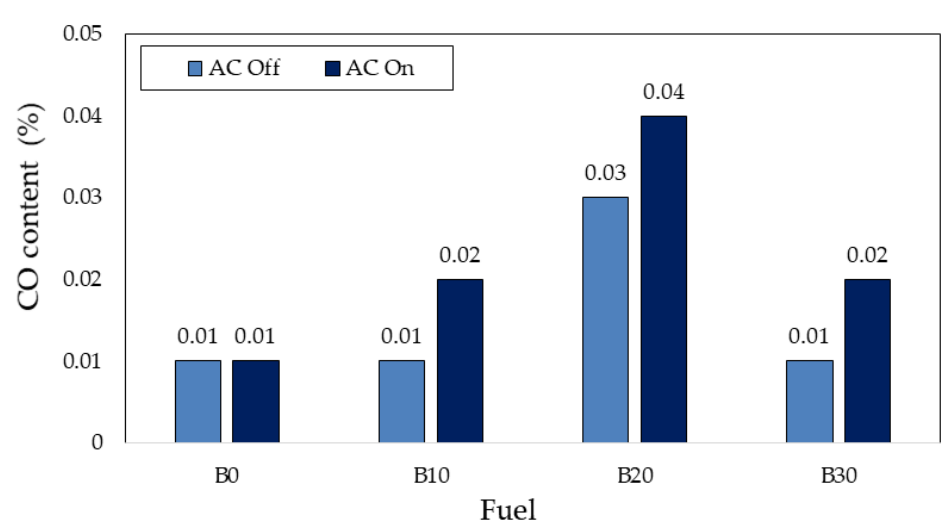

Figure 5. Comparison of CO emission with and without AC load.

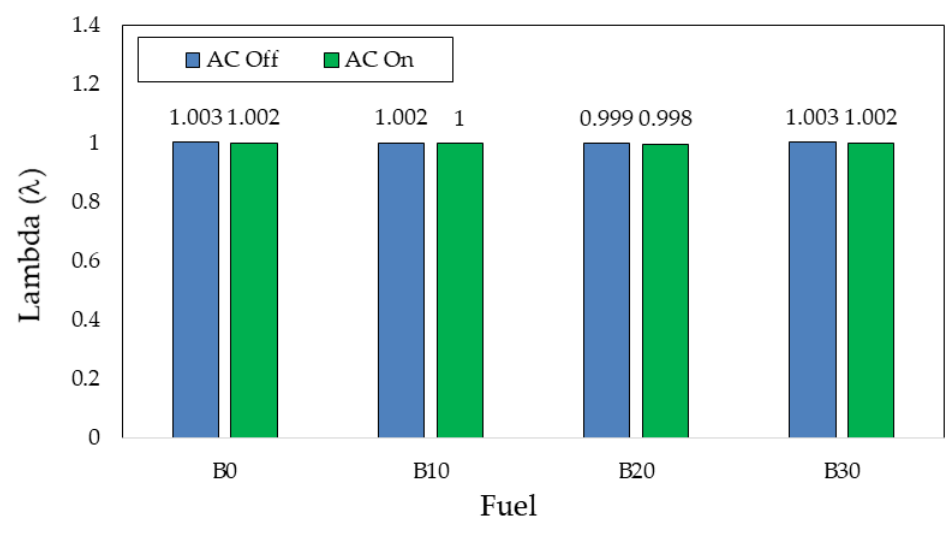

Figure 6. Comparison of lambda value with and without AC load.

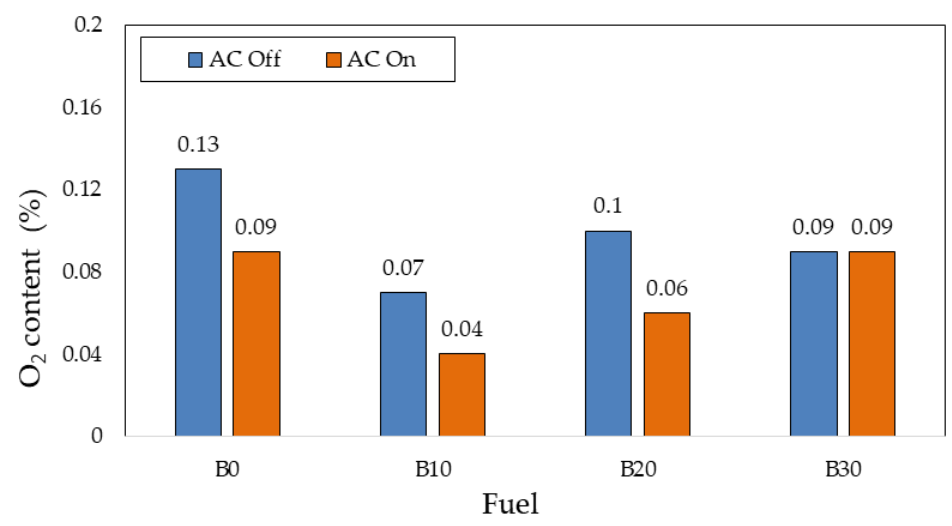

Figure 7. Comparison of $\mathrm{O}_{2}$ content with and without AC load. 


\section{Conclusion}

Based on the study conducted, it can be concluded that cassava biogasoline is a viable alternative fuel for EFI engine. B10 fuel mixture is found to have the lowest fuel consumption $(0.241$ $\mathrm{ml} / \mathrm{s}$ ) when used under urban traffic condition, compared to B20 and B30 mixtures. In addition, the results of emission tests showed that cassava biogasoline (B10, B20, B30) produces $\mathrm{CO}$ between $0.1-0.4 \%$, which is still under government regulation limit of $1.5 \%$.

\section{Acknowledgement}

This article is part of an alternative fuel development project for motor vehicles in the PSDKU Polinema Kediri, funded by the Ministry of Research, Technology and Higher Education - Republic of Indonesia. The authors would like to give their gratitude towards all the technicians and students who have been involved in this research project.

\section{References}

[1] Badan Pusat Statistik, "Perkembangan Jumlah Kendaraan Bermotor Menurut Jenis, 1949-2017," 2018. [Online]. Available: https://www.bps.go.id/linkTableDinamis/vi ew/id/1133. [Accessed: 07-Nov-2019].

[2] Deendarlianto et al., "Scenarios analysis of energy mix for road transportation sector in Indonesia," Renewable and Sustainable Energy Reviews, vol. 70, no. November, pp. 13-23, 2017.

[3] U.S Environmental Protection Agency, "Air Quality Index: a guide to air quality and your Health," Washington, DC, 2014.

[4] B. A. Prasetyo, D. A. Izani, M. Setiyo, N. Widodo, Saifudin, and B. C. Purnomo, "Estimasi Pemborosan Bahan Bakar Akibat Kemacetan Menggunakan Analisis Citra Google Map (Studi Kasus pada Simpang Armada Town Square Mall Magelang)," Automotive Experiences, vol. 1, no. 2, pp. 3642, 2018.

[5] A. Baswedan et al., "Problem Kemacetan
Jakarta," Update Indonesia, vol. 5, no. 5, pp. 125, 2010.

[6] C. Pothiraj, A. Arun, and M. Eyini, "Simultaneous saccharification and fermentation of cassava waste for Ethanol production," Biofuel Research Journal, vol. 2, no. 1, pp. 196-202, 2015.

[7] B. A. Adelekan, "Investigation of ethanol productivity of cassava crop as a sustainable source of biofuel in tropical countries," African Journal of Biotechnology, vol. 9, no. 35, pp. 5643-5650, 2010.

[8] K. Kuiper, L., Ekmekci, B., Hamelinck, C., Hettinga, W., Meyer, S., Koop, "Bio-ethanol from Cassava," Project number: PBIONL062937, no. November, pp. 1-13, 2007.

[9] D. G. Martinez, A. Feiden, R. Bariccatti, and K. R. de F. Zara, "Ethanol production from waste of cassava processing," Applied Sciences (Switzerland), vol. 8, no. 11, pp. 1-8, 2018.

[10] IEA, "Automotive Fuels for the Future- The Search for Alternatives," 2000.

[11] R. M. Ceballos, Bioethanol and Natural Resources: Substrates, Chemistry and Engineered Systems, 1st Editio. Florida: CRC Press, Taylor and Francis Group, 2017.

[12] S. Prasad and M. S. Dhanya, "Air Quality and Biofuels," in Environmental Impact of Biofuels, M. A. dos S. Bernardes, Ed. London: IntechOpen, 2011, pp. 227-250.

[13] B. Waluyo, I. N. G. Wardana, L. Yuliati, and M. N. Sasongko, "The role of molecule cluster on the azeotrope and boiling points of isooctane-ethanol blend," Fuel, vol. 215, no. September 2017, pp. 178-186, 2018.

[14] M. Wahyu and H. Rahmad, "The Effect of 10\% Bioetanol and Carbon Cleaner Mixtures with Engine Gurah Technique on The Level of CO Emission in Corolla Twincam AE92," VANOS Journal Of Mechanical Engineering Education, vol. 3, no. 2, pp. 163-172, 2018.

[15] A. Triwiyatno, E. W. Sinuraya, J. D. Setiawan, and S. Munahar, "Smart controller design of air to fuel ratio (AFR) and brake control system on gasoline engine," in 2nd 
International Conference on Information

Technology, Computer, and Electrical

Engineering, 2016, pp. 233-238.
[16] A. Hilier, Fundamentals of Motor Vehicle Technology, 6th Editio. Oxford: Oxford University Press, 2014. 